\title{
Assessment of Time Spent by Doctors on Medical Records: Initial Analysis and Preliminary Study
}

\author{
JACEK LORKOWSKI
}

Department of Orthopaedic and Traumatology, Central Clinical Hospital of Ministry of Interior and Administration, Warsaw, Poland

Faculty of Health Sciences, Medical University of Mazovia, Warsaw, Poland

\section{Oliwia GrZEGOROWsKa}

Department of Cardiology, Independent Public Regional Hospital in Szczecin, Poland

\begin{abstract}
The aim of the article is evaluation of time needed to spend on filling medical records by Polish surgeons. An anonymous questionnaire concerning time needed to spend on creating particular parts of medical documentation affecting one patient was filled by 80 doctors (40 specialists and 40 residents). $100 \%$ of the respondents stated that the time spent on medical records is excessive. In the whole study, the group time spent on records of one patient was as follows: without patterns and medical secretary 75.62 minutes (SD 7.4), with patterns - 53.3 minutes (SD 6.8), with the help of a medical secretary
\end{abstract}


36.72 minutes (SD 5.1). The results in the resident group were as follows: without patterns and medical secretary 110 minutes (SD 12.4), with patterns - 69.87 minutes (SD 9.4), with the help of a medical secretary 46.15 minutes (SD 6.5). In conclusion, taking legal, formal, and logistics measures could help to reduce the time spent on administrative procedures while generating medical documentation.

Keywords: working time, medical law, medical records, patterns, templates, bureaucracy, indirect costs, direct costs

JEL Classification Code: I18

\section{Introduction}

The history of mankind indicates that one of the attributes of the activities of homo sapiens (a rational man) is conscious leaving traces of activities, documenting them, i.e. creating various types of documentation. One of the first of such activities can be considered the rock drawings created during the period of Magdalenian culture, i.e. 17-15 thousand years B.C. in the Lascaux cave in Aquitaine. There is a colourful engraving of a man's probably multi-organ injury. Thus, it is possibly the first ever medical documentation available as a pictogram (Aujoulat, 2005; Lorkowski \& Jugowicz, 2020). With the rise of ancient civilizations, writing appeared, which is also a means of communication and creates the possibility of preserving the knowledge possessed by humans. The first medical records can be found in a medical treatise known as Edwin Smith Papyrus, dating from the 16th to 17th century B.C. However, modern medicine has been much more influenced by the Hippocratic School (460-370 B.C.) from the island of Kos, and the Corpus Hippocraticum in its structure resembles in part the current history of the disease (Gillum, 2013; Lorkowski \& Jugowicz, 2020).

Another significant step in the development of medical records took place in 1724, when the Medical Surgical Collegium called Charite was founded in Berlin. At the Collegium, probably for the first time in history, there was a rule that novice surgeons had to keep patient records in the form of a diary. This was expected and required by the first director of the institution, Johann T. Eller (1689-1760), who believed it to be the best form of education (Blanning, 1990; Frölich \& Oppenheim, 1877; Kaiser, 1986). Another significant historical modification in keeping medical records seems to be the introduction of patient records ('files'). These innovations started in the nineteenth century in Europe's major medical centres, Paris and Berlin. According to the research of Craig, this period is considered as crucial in introducing 
the prototype of modern documentation (Craig, 1989-1990; Craig, 1990; Hess, 2010; Reiser, 1991).

The progressing specialisation, which took place in the second half of the nineteenth century, influenced the changes in the structure and organisation of hospital work, but also the types of documentation in force. At the same time, there was a constant increase in the quantity of medical records, which were also copied, and detailed case descriptions were collected in libraries for scientific and didactic purposes (Engle, 1991; Howell, 1995; Siegler, 2010). In the late nineteenth and early twentieth centuries, medical records in selected centres in Europe and the United States began to resemble its present-day structure. Many institutions were involved in these activities, which increased the effectiveness and quality of treatment. In the United States, the Rockefeller Foundation had a significant impact on this (Flexner, 1910; Gillum, 2013). Around 1900 there was a general change in administrative technique. They started to bind documents which were combined into folders after the discharge of a patient. Attention was paid to the register, accounting data and finally, the documentation used at the patient's bedside. The introduction of the seal (today's stamp) was originally associated with the needs of accounting (1893). It was later confirmed in the register of patients (1900), and since 1925 the stamp has appeared during medical observations. According to Craig, it was connected with the introduction of 'business techniques' (Craig, 1989-1990; Craig, 1990; Hess, 2010; Howell, 1995). Medical data are also no longer dispersed. The first person to solve this problem is considered to be Plummer (1874-1937), who, based on the rules applicable in business and industry, began to attribute one 'record' to each patient. This took place in 1907 in the United States, in Mary's Hospital and Mayo Clinic (Camp et al., 2008; Gillum, 2013).

Due to the widespread introduction of health insurance, the role of medical records began to grow. In the United States, since 1880, medical records have also become evidence in insurance cases and possible abuse. The same thing happened in Europe. In Great Britain, for example, the 1911 Compulsory Social Security Act for working men between the ages of 16 and 70 required their medical records to be kept to a certain standard. A system of colour-coded envelopes and cards was introduced at that time, which lasted for decades, at least until 1970 (Fry \& Blake, 1956; Gillum, 2013; Tait, 1981). In 1916 in the United States it was recommended to save basic disease data in a standard form (the prototype of today's ICD 10) (Reiser, 2009; Siegler, 2010). Further revolutionary changes in record keeping began in the 1960s. Data started to be entered into electronic documentation, but then still based on punched cards. It was a tedious process. However, it provided greater opportunities to evaluate diagnostic and treatment processes for scientific, didactic, therapeutic, economic, and reporting purposes (Lorkowski \& Jugowicz, 2020; Tait, 1981). 
Currently, $80 \%$ of hospitals and doctor's offices in the United States use electronic medical records, which has allowed the creation of large electronic patient databases. They are a source of information used in treatment, in economic cost modelling, accounting for medical procedures, but also in many other important aspects such as scientific research. In the feedback mechanism, programmes for searching and analysing data based on artificial intelligence techniques are adapted to the operating databases; on the other hand, the created new databases are adapted to the existing 'engines' functioning on the basis of artificial intelligence (Lorkowski \& Jugowicz, 2020; Mearian, 2018).

In modern Europe, electronic medical documentation is also dominant. A prime example of the introduction of full electronic documentation is Estonia, which is currently the world's most highly-digitalised country. The entire Estonian society is already practically paperless, which allows the state to save as much as $2 \%$ of GDP annually. From a technical point of view, the whole thing is based on blockchain technology, which is a chain of blocks without central computers (Hölbl et al., 2018; Lorkowski \& Jugowicz, 2020).

Thus, as in previous centuries, the creation of medical records is a part of work of contemporary doctors in every country. However, its excess leads to the underutilisation of each doctor's medical knowledge, experience and professional burnout, which is to a large extent contrary to the concept of VRIO (Value, Rarity, Imitability, Well Organisation), in particular the proper use of key resources (Rostkowski, 2018; VRIO, 2020).

The aim of this study was to estimate the amount of time that a doctor with surgical specialisation has to devote to complete the entire medical records of one patient treated.

\section{Data and methodology}

The survey conducted in the first half of 2019 was carried out in a manner ensuring full anonymity of 80 doctors (40 specialists and 40 residents) working in surgical wards in Poland. Persons who complete medical records were qualified for the study. In the case of specialists, persons commissioning residents to fill in the survey were excluded from the study. In order to objectivise the results, no surveys were conducted in the centres where the authors work. Each of the respondents was asked the same questions:

1) Is the amount of medical records you fill in and the amount of time you spend on this appropriate? (Possible answers: A. yes, appropriate; B. excessive; C. definitely excessive). 
2) Do you use modifiable templates ('ready-made') when completing medical records? (Possible answers: A. yes, always (or almost always); B. from time to time; $C$. never).

3) Can you record in an electronic medium a description of your interview, physical examination, medical observation, discharge and have it transcribed by a medical secretary? (Possible answers: A. yes; B. from time to time; C. never).

4) Irrespective of whether the examined person answered that they used modifiable templates and whether they used help of a medical secretary, the question was asked about the time (in minutes) he or she spends on filling in the documentation related to the patient's admission, surgery, daily treatment and discharge - both when using a text template, the possibility of having the medical secretary to rewrite the text and in the absence of such possibilities. The time for the 'average' patient was asked.

5) The next questions concerned the time (in minutes) for ordering medicines and tests. Again, the request for a time related to the 'average' patient was asked.

The groups of residents and specialists were analysed and the results in both groups were compared. The results were processed with the use of Microsoft Office Excel.

When constructing the survey, its scope was deliberately limited due to the fact that it was considered that a more probable and credible answer could be obtained to a few basic questions, rather than to a dozen or even more detailed ones.

\section{Results}

All 80 respondents considered that they spend too much time on filling in medical records (100\% of answers: "I complete an excessive amount of medical records"). Constant use of modifiable description templates was confirmed by 24 specialists, and the answer "from time to time" was considered appropriate by 16 . For the surveyed residents, the results were as follows: using description templates - 36 persons, using them "from time to time" - 3 doctors, and not using description templates -1 person. The possibility of using the help of a medical secretary "from time to time" to rewrite an interview, examination, description of the procedure, decursus, or discharge was confirmed by 4 specialists. None of the specialists or residents had a permanent medical secretary for this type of procedure.

In the whole study group, among specialists, the average time required to complete the whole medical documentation of one patient was: without the use of templates and the help of a medical secretary - 75.62 minutes (SD 7.4), if templates are used - 53.3 minutes (SD 6.8), and with the help of a medical secretary - 36.72 minutes (SD 5.1). In the case of the residents, the results were as follows: without the use of 
modifiable text templates and the help of the secretary - 110 minutes (SD 12.4), with the use of templates - 69.87 minutes (SD 9.4) and with the help of a medical secretary -46.15 minutes (SD 6.5). A detailed summary of the most important survey results is presented in the table (Table 1 ).

Table 1. A summary of working time (the result provided in minutes), allocated for the preparation of all medical records by specialists and residents in the examined group (basic parameters of the set of measurements)

\begin{tabular}{|l|c|c|c|c|c|c|}
\cline { 2 - 7 } \multicolumn{1}{c|}{} & $\begin{array}{c}\text { Specialist } \\
\text { without } \\
\text { a description } \\
\text { template }\end{array}$ & $\begin{array}{c}\text { Specialist } \\
\text { with } \\
\text { a description } \\
\text { template }\end{array}$ & $\begin{array}{c}\text { Specialist } \\
\text { with the } \\
\text { help of } \\
\text { a secretary }\end{array}$ & $\begin{array}{c}\text { Resident } \\
\text { without } \\
\text { a template }\end{array}$ & $\begin{array}{c}\text { Resident } \\
\text { with } \\
\text { a description } \\
\text { template }\end{array}$ & $\begin{array}{c}\text { Resident } \\
\text { with the } \\
\text { help of } \\
\text { a secretary }\end{array}$ \\
\hline Average & $\begin{array}{c}75.62 \\
\text { (SD 7.4) }\end{array}$ & $\begin{array}{c}53.3 \\
(\text { SD 6.8) }\end{array}$ & $\begin{array}{c}36.72 \\
\text { (SD 5.1) }\end{array}$ & $\begin{array}{c}110 \\
\text { (SD 12.4) }\end{array}$ & $\begin{array}{c}69.87 \\
(\text { SD 9.4) }\end{array}$ & $\begin{array}{c}46.15 \\
\text { (SD 6.5) }\end{array}$ \\
\hline Dedian & 75 & 52,5 & 37 & 110 & 70 & 48 \\
\hline Maximum & 90 & 65 & 47 & 110 & 70 & 48 \\
\hline Minimum & 65 & 40 & 25 & 90 & 50 & 57 \\
\hline Skewing & 0,22 & 0,04 & $-0,07$ & 0,13 & 0,27 & $-0,35$ \\
\hline Kurtosis & 17,56 & 9,82 & 7,29 & $-6,63$ & $-0,24$ & $-0,47$ \\
\hline
\end{tabular}

Source: own study.

Data on the time spent by specialists and residents on documentation of admission to the ward, surgery, daily treatment procedures and discharge showed a similar trend. The time needed for preparing the documentation was longer than when the template was not used, and it was the lowest when the medical secretary also helped with the documentation. This applied to both specialists and residents. The median and the dominant in the case of studies on specialists were analogous and very close to the average. Slightly larger differences were found for residents. The median was different from the dominant one in 3 cases (filling in the treatment documentation with the help of a medical secretary; discharging without the help of a modifiable text template and medical secretary; prescribing medicines). However, apart from the time of prescribing medication, these were not significant differences (prescribing medicines: median 10 minutes, dominant 15 minutes). The average was also similar to the dominant and median in all the cases. The exact data for all the analysed procedures is presented in the tables (Tables 2-6).

In order to illustrate better the obtained results, the average values of time needed to complete documentation of one patient by a specialist and a resident in each of the 3 considered variants (without the help of text templates and a medical secretary, 
with the help of text templates and with the help of a secretary) were ranked from the lowest to the highest value. Based on the data obtained, a line diagram was made, which shows the data obtained (Figure 1). In a marginal number of cases it presents the contact or crossing of the graphs. This applies mainly when medical records are completed by specialists with the help of a text template or secretary.

Table 2. A summary of working time (the result provided in minutes) of a specialist and a resident physician, intended for creating medical records related to the admission of a patient to hospital

\begin{tabular}{|c|c|c|c|c|c|c|}
\hline & $\begin{array}{c}\text { Specialist } \\
\text { without } \\
\text { a description } \\
\text { template }\end{array}$ & $\begin{array}{c}\text { Specialist } \\
\text { with } \\
\text { a description } \\
\text { template }\end{array}$ & $\begin{array}{c}\text { Specialist } \\
\text { with the } \\
\text { help of } \\
\text { a secretary }\end{array}$ & $\begin{array}{c}\text { Resident } \\
\text { without } \\
\text { a template }\end{array}$ & $\begin{array}{c}\text { Resident } \\
\text { with } \\
\text { a description } \\
\text { template }\end{array}$ & $\begin{array}{l}\text { Resident } \\
\text { with the } \\
\text { help of } \\
\text { a secretary }\end{array}$ \\
\hline Average & $\begin{array}{c}11.75 \\
(S D 2.7)\end{array}$ & $\begin{array}{c}6.65 \\
(S D 2.1)\end{array}$ & $\begin{array}{c}4.55 \\
\text { (SD 0.8) } \\
\end{array}$ & $\begin{array}{c}17.87 \\
(\mathrm{SD} 4.4) \\
\end{array}$ & $\begin{array}{c}10.25 \\
(S D 3.5) \\
\end{array}$ & $\begin{array}{c}5.92 \\
(S D 2.5) \\
\end{array}$ \\
\hline Median & 10 & 5 & 5 & 20 & 10 & 5 \\
\hline Dominant & 10 & 5 & 5 & 20 & 10 & 5 \\
\hline Maximum & 20 & 10 & 5 & 25 & 20 & 10 \\
\hline Minimum & 10 & 5 & 3 & 10 & 4 & 3 \\
\hline
\end{tabular}

Source: own study.

Table 3. A summary of working time (the result provided in minutes) of a specialist and a resident physician, intended for the creation of medical records related to daily observations and other documents created on an ongoing basis during the patient's hospitalisation

\begin{tabular}{|l|c|c|c|c|c|c|}
\cline { 2 - 7 } \multicolumn{1}{c|}{} & $\begin{array}{c}\text { Specialist } \\
\text { without } \\
\text { a description } \\
\text { template }\end{array}$ & $\begin{array}{c}\text { Specialist } \\
\text { with } \\
\text { a description } \\
\text { template }\end{array}$ & $\begin{array}{c}\text { Specialist } \\
\text { with the } \\
\text { help of } \\
\text { a secretary }\end{array}$ & $\begin{array}{c}\text { Resident } \\
\text { without } \\
\text { a template }\end{array}$ & $\begin{array}{c}\text { Resident } \\
\text { with } \\
\text { a description } \\
\text { template }\end{array}$ & $\begin{array}{c}\text { Resident } \\
\text { with the } \\
\text { help of } \\
\text { a secretary }\end{array}$ \\
\hline Median & 10.12 & $\begin{array}{c}4.75 \\
\text { (SD 2.6) }\end{array}$ & $\begin{array}{c}2.8 \\
\text { (SD 1.1) }\end{array}$ & 13 (SD 3.5) & 7.1 (SD 2.7) & $\begin{array}{c}3.6 \\
\text { (SD 1.7) }\end{array}$ \\
\hline Dominant & 10 & 5 & 2 & 10 & 5 & 3 \\
\hline Maximum & 20 & 10 & 2 & 10 & 5 & 5 \\
\hline Minimum & 5 & 2 & 2 & 10 & 5 & 10 \\
\hline
\end{tabular}

Source: own study. 
Table 4. A summary of working time (the result provided in minutes) of a specialist and a resident physician, intended for the creation of all medical records directly related to the surgical procedure of the hospitalised patient

\begin{tabular}{|c|c|c|c|c|c|c|}
\hline & $\begin{array}{c}\text { Specialist } \\
\text { without } \\
\text { a description } \\
\text { template }\end{array}$ & $\begin{array}{c}\text { Specialist } \\
\text { with } \\
\text { a description } \\
\text { template }\end{array}$ & $\begin{array}{l}\text { Specialist } \\
\text { with the } \\
\text { help of } \\
\text { a secretary }\end{array}$ & $\begin{array}{c}\text { Resident } \\
\text { without } \\
\text { a template }\end{array}$ & $\begin{array}{c}\text { Resident } \\
\text { with } \\
\text { a description } \\
\text { template }\end{array}$ & $\begin{array}{c}\text { Resident } \\
\text { with the } \\
\text { help of } \\
\text { a secretary }\end{array}$ \\
\hline Average & $\begin{array}{c}17.12 \\
(S D 2.7)\end{array}$ & $\begin{array}{c}11.9 \\
(S D 2.4)\end{array}$ & $\begin{array}{c}5.9 \\
(S D 1.9)\end{array}$ & $\begin{array}{c}20.12 \\
(\mathrm{SD} 3.5)\end{array}$ & $\begin{array}{c}13.75 \\
(\mathrm{SD} 3.0)\end{array}$ & $\begin{array}{c}7.75 \\
\text { (SD 2.5) }\end{array}$ \\
\hline Median & 15 & 10 & 5 & 20 & 15 & 10 \\
\hline Dominant & 15 & 10 & 5 & 20 & 15 & 10 \\
\hline Maximum & 25 & 15 & 10 & 25 & 20 & 10 \\
\hline Minimum & 15 & 10 & 5 & 15 & 10 & 5 \\
\hline
\end{tabular}

Source: own study.

Table 5. The summary of working time (the result provided in minutes) of a specialist and a resident physician, intended for the creation of all medical records directly related to the discharge of a hospitalised patient

\begin{tabular}{|c|c|c|c|c|c|c|}
\hline & $\begin{array}{c}\text { Specialist } \\
\text { without } \\
\text { a description } \\
\text { template }\end{array}$ & $\begin{array}{c}\text { Specialist } \\
\text { with } \\
\text { a description } \\
\text { template }\end{array}$ & $\begin{array}{l}\text { Specialist } \\
\text { with the } \\
\text { help of } \\
\text { a secretary }\end{array}$ & $\begin{array}{c}\text { Resident } \\
\text { without } \\
\text { a template }\end{array}$ & $\begin{array}{c}\text { Resident } \\
\text { with } \\
\text { a description } \\
\text { template }\end{array}$ & $\begin{array}{c}\text { Resident } \\
\text { with the } \\
\text { help of } \\
\text { a secretary }\end{array}$ \\
\hline Average & $\begin{array}{c}18.5 \\
\text { (SD 2.8) }\end{array}$ & $\begin{array}{c}11.87 \\
(\mathrm{SD} 2.7)\end{array}$ & $\begin{array}{c}5.37 \\
\text { (SD 1.3) }\end{array}$ & $\begin{array}{c}39 \\
(S D 10.9)\end{array}$ & $\begin{array}{c}18.75 \\
(\mathrm{SD} 6.0)\end{array}$ & $\begin{array}{c}8.87 \\
\text { (SD 2.9) }\end{array}$ \\
\hline Median & 20 & 10 & 5 & 42,5 & 20 & 10 \\
\hline Dominant & 20 & 10 & 5 & 45 & 20 & 10 \\
\hline Maximum & 25 & 15 & 10 & 60 & 30 & 15 \\
\hline Minimum & 15 & 5 & 5 & 20 & 10 & 5 \\
\hline
\end{tabular}

Source: own study.

Table 6. A summary of working time (the result provided in minutes) of a specialist physician and a resident, intended for issuing daily orders for the hospitalised patient

\begin{tabular}{|l|c|c|c|c|}
\cline { 2 - 5 } \multicolumn{1}{c|}{} & $\begin{array}{c}\text { Specialist } \\
\text { - commissioning } \\
\text { medical } \\
\text { examination }\end{array}$ & $\begin{array}{c}\text { Specialist } \\
\text { - commissioning } \\
\text { administration of } \\
\text { medicines }\end{array}$ & $\begin{array}{c}\text { Resident } \\
\text { - commissioning } \\
\text { medical } \\
\text { examination }\end{array}$ & $\begin{array}{c}\text { Resident } \\
\text { - commissioning } \\
\text { administration of } \\
\text { medicines }\end{array}$ \\
\hline Average & $7.75($ SD 2.5) & 10.37 (SD 3.1) & 8.5 (SD 3.0) & 11.5 (SD 4.3) \\
\hline Median & 10 & 10 & 10 & 10 \\
\hline
\end{tabular}




\begin{tabular}{|l|c|c|c|c|}
\cline { 2 - 5 } \multicolumn{1}{c|}{} & $\begin{array}{c}\text { Specialist } \\
- \text { commissioning } \\
\text { medical } \\
\text { examination }\end{array}$ & $\begin{array}{c}\text { Specialist } \\
\text { - commissioning } \\
\text { administration of } \\
\text { medicines }\end{array}$ & $\begin{array}{c}\text { Resident } \\
\text { - commissioning } \\
\text { medical } \\
\text { examination }\end{array}$ & $\begin{array}{c}\text { Resident } \\
- \text { commissioning } \\
\text { administration of } \\
\text { medicines }\end{array}$ \\
\hline Dominant & 10 & 10 & 10 & 15 \\
\hline Maximum & 10 & 15 & 15 & 20 \\
\hline Minimum & 5 & 5 & 5 & 5 \\
\hline
\end{tabular}

Source: own study.

Figure 1. Comparison of the working time of a specialist physician and a resident doctor when completing all medical records - without a text template vs. with a text template vs. with the help of a medical secretary

(For the purpose of visualisation and comparability, the data on the abscissa axis is arranged from the smallest to the largest, the time in minutes is marked on the ordinate axis).

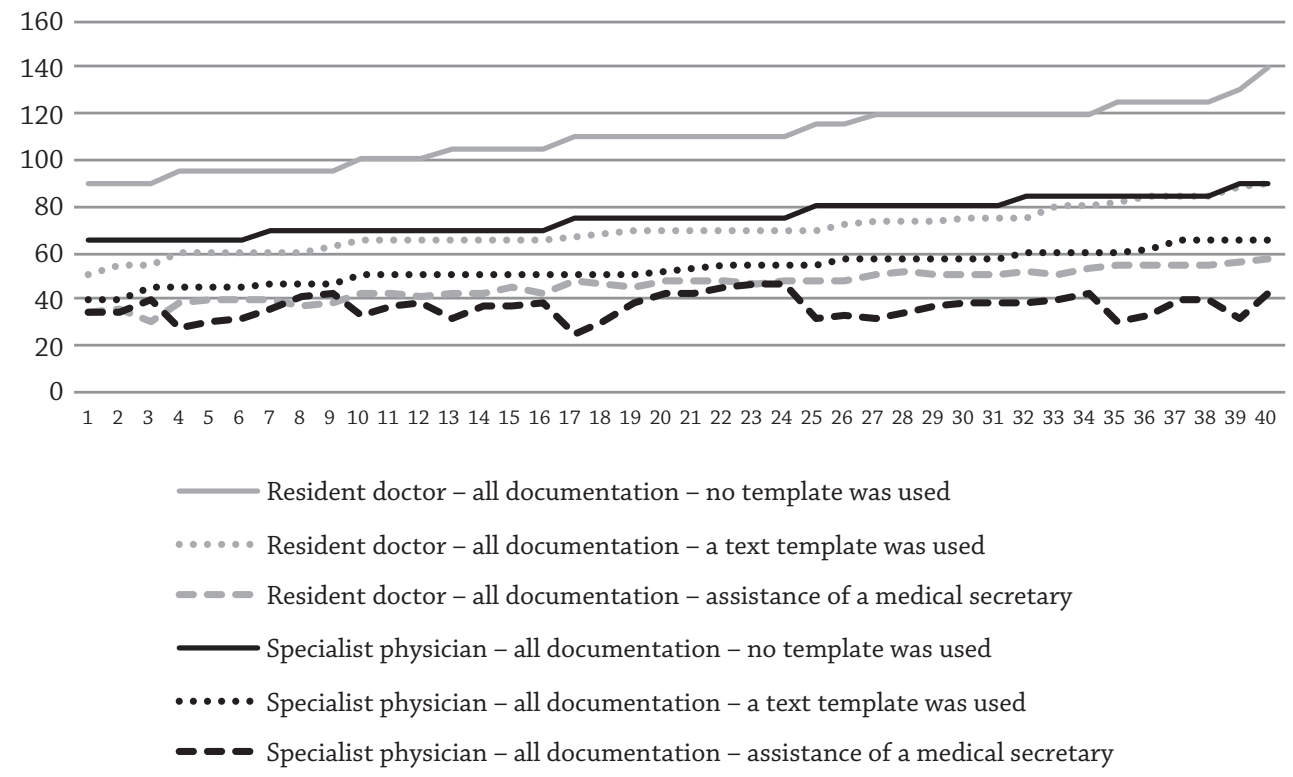

Source: own study.

\section{Discussion}

The basis for creating medical records in their current form is the legal regulations in force in a given country. In Poland, these are regulations resulting from general law, industry regulations, including those imposed by the insurer, i.e. the National 
Health Fund (NFZ), and internal arrangements. The most important of the regulations conditioning the creation of medical records in Poland is the Act of 5 April 2011 on Medical Activity (DzU 2018.160), i.e. Article 2(1) (b) of Regulation (EC) No. 1/2003. 1 of this Act, as well as professional pragmatics, i.e. the Act of 5 December 1996 on the professions of doctor and dentist (DzU 2018.617), and in particular Article 41 of the Act on the scope of keeping medical records, and regulations contained in the provisions of the Act of 6 November 2008 on patient rights and the Patient Ombudsman (DzU 2017.1318). In the latter, Chapter 7, Articles 23 to 30a, and the implementing acts issued on this basis, are the most relevant for medical records: the Ordinance of the Minister of Health of 9 November 2015 on the types, scope and models of medical records and the method of their processing, and the Ordinance of the Minister of Internal Affairs of Administration of 25 February 2016 on the types, scope and models of medical records and the method of their processing in medical entities established by the minister in charge of internal affairs. In some cases, the decisions of both Polish and international scientific societies also oblige to create certain annexes to medical records. This applies, for example, to documents related to the registration of implants (Lorkowski, Wilk, 2017).

Some of the time-consuming activities related to the maintenance of medical records are the result of new recommendations, which are emerging from year to year, and which are based on new legal conditions. It is commonly felt that this problem exists and has been growing not for several years, but for several decades. Currently, according to international rankings, Poland is one of the most bureaucratic countries of the European Union. What is important, and which should be clearly emphasised once again, this is not a problem that has arisen in recent years (Przyrost Dokumentów, 2019). In healthcare, unfortunately, each of the procedures associated with filling in medical records takes a certain period of time, distracting the doctor from the main task, which is to treat patients. For example, in orthopaedics, such an additional procedure is to report the implant to the Central Endoprosthesis Database. In itself, the idea of a central register of endoprostheses is a very good one, modelled on Scandinavia. It has proven its worth in the central model register of endoprostheses introduced in Sweden. Similar implant registers also exist in many other countries. However, the problem is that it is not the doctor but the medical secretary who enters the necessary data there (The Swedish knee arthroplasty register, 2014). Therefore, there is a problem of time needed for doctors in Poland to perform bureaucratic-administrative procedures. Any procrastination does not solve anything here. The situation is in line with Parkinson's law, which states that "work expands to fill the time available for completion" (Parkinson, 1971). Surveys conducted among residents may even indicate that the problem exceeds the framework set by this law. In the study, which is being carried out and currently described by the author, all 
doctors notice the excessive expansion of medical records. This is consistent with the results of previous studies (Gawande, 2018; Lorkowski et al., 2020). Precise analyses indicate that the average total time spent on documentation completion for one patient, in the most frequently used version, i.e. using text templates, is 53.3 minutes (SD 6.8) for a specialist and 69.87 minutes (SD 9.4) for a resident. It should be noted that the survey did not include questions about the number of patients supplied by one doctor during the working day. The author's previous research on the time spent by residents on such activities indicated that these values were very high (Lorkowski, Wilk, 2017). The average values of the time needed to fill in medical records in accordance with the norms varied depending on the mode of action. In the case of writing all the valid formulas by oneself, this time was the highest (the specialists - 75.62 minutes (SD 7.4); the residents - 110 minutes (SD 12.4), respectively). The use of templates for prepared descriptions reduced it, and the possible assistance of a secretary minimised it (specialists - 36.72 minutes (SD 5.1); residents -46.15 minutes (SD 6.5)). The full optimisation of actions would be achieved in the case of relieving the doctor from bureaucratic work through the widespread introduction of medical secretaries (eventually medical secretaries and artificial intelligence techniques) (Lorkowski \& Malinowska, 2020). They would then devote about 15-20 minutes less to all the administrative procedures involved in filling in medical records for a single patient than when text templates are used. However, the answers to the question about the time it takes to complete medical records with the help of a medical secretary may be unreliable. A vast majority of the respondents never had an opportunity to take advantage of such assistance. If they used the help of a medical secretary, it was only for registering a patient, arranging the documentation or similar activities that ended the patient service. Therefore, the figures given by doctors can be estimates only. A certain view of the possibilities of implementing help from medical secretaries and nurses for the receiving patients in the outpatient clinic can be gained by talking to the staff of individual institutions where this takes place. The algorithm used there is widely known and used in Western European countries. One doctor will see the patient 'in two or three offices'. In the first office, the patient enters, undresses, prepares for a medical examination, and the nurse conducts a medical interview. In the second room, the doctor examines another patient, possibly supplementing the interview with elements of interest. In the third office, already examined by the doctor, the medical secretary prints all necessary referrals or prescriptions and fills in the medical records. The authors have personally come into contact with this model in Austria, Belgium, Finland, Germany and Israel. It was effective despite the appearance of dehumanisation and tape action. Everyone paid attention not to waste the time of a key resource such as the doctor, while waiting for an ailing person to undress. The patient was provided with a sense 
of security and no 'rush'. According to the authors' observations, a similar algorithm is used as a standard in the countries mentioned above when patients are admitted to the ward, which is the case with the questionnaire analysed in this study. This requires additional rooms and appropriate ergonomics.

The nature of the study (questionnaire survey) made it impossible to verify the results on an ongoing basis. However, the subjective feeling of the authors seems to be in line with reality. American experience shows that the local doctor of a surgical speciality spends at least 2 hours a day filling in medical records (Gawande, 2018). If one takes into account the number of patients led by one doctor and the availability of medical secretaries, then in Poland the time spent on administrative procedures by both a specialist and a resident must probably be greater.

This problem is very serious when we take into account the costs that this situation causes.

The data available for analysis are:

- 8 million, as an estimate of the number of people hospitalised in Poland during the year (according to the data of Statistics Poland, in 2017 about 7,773,000 people were hospitalised in general hospitals and 195,800 in the stationary mode in psychiatric hospitals).

- the doctor allocates for one patient's documentation 76 minutes, 53 minutes, 36 minutes, 110 minutes, 70 minutes and 46 minutes, respectively (according to the obtained test results).

- average doctor's salary is PLN 86.78 per hour (calculated on the basis of data collected by the Agency for Health Technology Assessment and Tariffs covering the treatment in 2016, which was updated with the indices of annual growth of remuneration costs in the healthcare sector, developed by Statistics Poland, amounting in subsequent years to $5.4 \%, 8.6 \%$ and $12.2 \%$, respectively (Agency for the Protection of Medical Technology and Tariffs; communiqué of the President of the CSO of 11 February 2019) (Agency for Health Technology Assessment and Tariffs; Announcement of the President of the Central Statistical Office of 11 February 2019).

The costs of medical records are, therefore, quantifiable. For all patients hospitalised in Poland during the year, with the assumed simplifications (including, among others, uniform doctor's remuneration), they would be equal to the time spent on the procedure: for 110 minutes - PLN 1,272,773,333; 76 minutes - PLN 879,370,667; 70 minutes - PLN 809,946,667; 53 minutes - PLN 613,245,333; 46 minutes - PLN 532,250,667; 36 minutes - PLN 416,544,000. Even if it were to be assumed that the subjective assessments of the respondents could cause an error in the measurements made on their basis by a dozen or even several dozen percent, these costs are enormous. When using a medical secretary, it should be remembered that 
this also results in costs related to her/his employment. For the sake of simplicity, it was assumed that the time of the medical secretary's work with the records of one patient would be such as the difference between the time that the doctor would devote to work with the records without the help of an additional person and the time that they would devote to this activity in cooperation with the secretary. Based on the data above, it was assumed that the remuneration of a medical secretary is PLN 26.25 per hour. It was found that the cost of medical records prepared by a physician, together with a medical secretary, would be PLN 553,044,000 for all patients treated during the year in Poland if it took 76 minutes for one patient and PLN 756,250,667 if the procedure for one patient took 110 minutes. These calculations are considerably simplified as they include the average remuneration of doctors (specialists and residents). The difference between a doctor filling in the documentation by himself or herself and the actions performed together with a secretary, on the scale of all patients treated in Poland during the year, in two simulated cases ( 110 and 76 minutes of procedures in progress) would be: PLN 516,522,667 and PLN 326,326,667. The order of magnitude of the costs we are talking about here is huge, regardless of the accuracy of calculations (Lorkowski, 2019).

An interesting problem seems to be the relation between the time indicated by the respondents, which is necessary to complete medical records correctly, and the time that is actually devoted to it. This requires further research. Here one may find an explanation to the conclusions concerning the quality of medical records from the inspection carried out by the Supreme Audit Office at the turn of 2018/2019 in healthcare facilities.

The very feelings of the respondents regarding the time spent not at the patient's bedside but on filling in medical records are also important as a factor affecting people, i.e. from the economic point of view - human capital. Without this attribute, work becomes meaningless ("One of the most painful forms of betrayal is to condemn a working man to work without meaning") (Tischner, 2000).

A doctor's many hours' withdrawal from medical procedures in favour of formal and legal procedures must raise doubts as to the validity of the current algorithms. This leads to an increase in both direct and indirect costs.

The proposed corrective actions should, according to the authors, take into account three elements:

- current legislation;

- the standard of medical documentation functioning several decades ago;

- the possibility of using artificial intelligence techniques to automatically generate text (Lorkowski \& Wilk, 2017).

It should be remembered that at the moment, medical records cover several dozen pages. Medical documentation in Poland in the 1960 s was on 4 rarely written pages. 
Without the risk of making a mistake, it can be assumed that nowadays a doctor has to write at least 10 times more text in the documentation than a few decades ago. It does not mean that so much more information is introduced. A large part of the history of the disease is made up of repetitions. From the point of view of the doctor's needs, the histories of diseases from the 1960s, which the authors of the paper came across, contained a very similar, if not the same amount of relevant information. For example, currently every day the medical decree and nursing observation is to be entered in the patient's records. Each entry contains at least a few sentences. According to previous standards, which were created by 'masters of today's teachers', if nothing important happened to the patient and the treatment was the same as before, the entry 'rr-mm-dd' was enough. 'Bene.' or 'rr-mm-dd.Th.idem.' This meant exactly the same as the current several-sentence decursus, which is the most frequently copied template anyway. It should be noted that with the annotation 'bene' or 'th. idem' is similar to a pictogram. One does not have to read into it, just a fraction of a second is enough to get all the information you give in the documentation. If one read the pasted 'template', the situation is more complicated, because you have to read it very carefully. Between a few lines of standard text meaning 'th.idem' may contain one or two words that change the sense of the decapitation (e.g.: stitches removed vs. $1 / 2$ stitches removed, or: full load of the operated limb vs. trace load of the operated limb). This is a problem of quality of treatment, but also of costs. Typing in or 'pasting in' text that is unnecessary for whole generations of doctors reduces the amount of time that can be spent on other activities. This applies to both writers ('pasting') and readers. At this point it should be stressed that time is an economic resource.

Bearing in mind that it is always possible to change the legal interpretation of medical records, it is worth taking into account in any proposals:

- the possibility of not duplicating the same information in different places in the documentation;

- consider the need to include information on standard activities in the documentation;

- recognition as fully-fledged and sufficient (from the formal and legal point of view) sound, photographic or film recording replacing in some cases the 'classic' written documentation (printed or, according to the planned changes, 'written' but kept on a digital medium).

From the point of view of the logistics of operation, it seems to be advisable:

- introduction of pictographic diagrams in computer systems, enabling very quick completion of documentation;

- introduction of artificial intelligence systems to facilitate the generation of medical records (speech recognition systems that convert speech into a text document); 
- modification and improvement of the electronic system of ordering medicines and tests necessary for a given patient so that they are entered from a portable device (e.g. tablet or phone) connected to the central database.

The proposed changes may seem revolutionary, however, the introduction of at least some of them seems to be the only adequate response to the growing bureaucratisation of not only Polish but also world medicine for at least several dozen years, which is contrary to the development of new technologies. There is no reasonable indication that the current normative system cannot be changed. One cannot generate professional burnout of doctors and nurses and their permanent exhaustion. These phenomena have been thoroughly investigated in the United States, as well as their negative consequences (Lorkowski \& Wilk, 2017; Maslach \& Schaufeli, 1993).

To sum up, it should be emphasised once again that the discussed problem is not only a Polish one, and that it has not arisen in the last few years, but it is a problem of the lack of appropriate decisions, which took place over several decades (Gawande, 2018; Lorkowski et al., 2020). When discussing the shortage of medical personnel in the era of the Covid-19 epidemic, one should pay attention, among others, to this problem. Reducing the amount of medical records means increasing the time that medical personnel can devote to the patient. It is because of the ongoing Covid-19 epidemic that the fastest possible solution to this problem, i.e. the actual optimisation of the documentation, would be advisable.

\section{Conclusion}

It seems justified to implement formal, legal and logistic measures reducing the time spent on administrative procedures related to the generation of medical records.

\section{References}

Agencja Oceny Technologii Medycznych i Taryfikacji (2016). Świadczenia gwarantowane obejmujące leczenie złamań i zwichnięć identyfikowane produktami: H60-H67, WT.521.22.2016.

Aujoulat, N. (2005). Lascaux: movement, space and time. New York: Published by Harry N. Abrams.

Blanning, T.C.W. (1990). Frederick the great and enlightened absolutism. In: H.M. Scott (Ed.), Enlightened absolutism. Reform and reformers in later eighteenth-century Europe. New York: Published by Palgrave Macmillan. 
Camp, C.L., Smoot, R.L., Kolettis, T.N., Groenewald, C.B., Greenlee, S.M., \& Farley, D.R. (2008). Patient records at Mayo Clinic: lessons learned from the first 100 patients in Dr Henry S. Plummer's dossier model. Mayo Clin Proc., 83(12), 1396-1399.

Craig, B.L. (1989-1990). Hospital records and record-keeping, c. 1850-c. 1950. Part I: The development of records in hospitals. Archivaria, 29, 57-80.

Craig, B.L. (1990). Hospital records and record-keeping, c. 1850-c. 1950. Part II: The development of record-keeping in hospitals. Archivaria, 30, 21-38.

Engle, R.L. Jr. (1991). The evolution, uses, and present problems of the patient's medical record as exemplified by the records of the New York Hospital from 1793 to the present. Trans Am Clin Climatol Assoc, 102, 182-189; discussion 189e192.

Flexner, A. (1910). Medical education in the United States and Canada: A report to the Carnegie Foundation for the advancement of teaching (Bull. 4). New York City.

Frölich, H., \& Oppenheim, A. (1877). Eller, Johann Theodor. In: Allgemeine Deutsche Biographie (ADB). Band 6, Leipzig: Duncker \& Humblot.

Fry, J., \& Blake, P. (1956). Keeping of records in general practice. The British Medical Journal, 1 (Suppl 2681), 339-341.

Gawande, A. (2018). Why doctors hate their computers. Annals of Medicine, November 12. The New Yorker. Retrieved from: https://www.newyorker.com/magazine/2018/11/12/ why-doctors-hate-their-computers (accessed: 20.10.2020)

Gillum, R.F. (2013). From papyrus to the electronic tablet: a brief history of the clinical medical record with lessons for the digital age. American Journal of Medicine, 126(10), 853-857.

Hess, V. (2010). Formalisierte beobachtung. Die genese der modernen krankenakte am beispiel der Berliner und Pariser medizin (1725-1830). Medizinhist Journal, 45 (3-4), 293-340.

Howell, J.D. (1995). Technology in the hospital: Transforming patient care in the early twentieth century Baltimore. Baltimore: Johns Hopkins University Press.

Hölbl, M., Kompara, M., Kamišalic, A., \& Zlatolas, L.N. (2018). A systematic review of the use of blockchain in healthcare. Symmetry, 10, 470.

Kaiser, W. (1986). Ars medica Anhaltina: zum 225. Todestag von Johann Theodor Eller (1689-1760). Z Gesamte Inn Med, 41(7), 202-208.

Komunikat Prezesa Głównego Urzędu Statystycznego z dnia 9 lutego 2017 r. w sprawie realnego wzrostu przeciętnego wynagrodzenia. Retrieved from: https://stat.gov.pl/ sygnalne/komunikaty-i-obwieszczenia/lista-komunikatow-i-obwieszczen/komunikat-w-sprawie-realnego-wzrostu-przecietnego-wynagrodzenia-w-2018-roku-wstosunku-do-2017-roku,274,6.html (accessed: 31.10.2020).

Komunikat Prezesa Głównego Urzędu Statystycznego z dnia 9 lutego 2018 r. w sprawie realnego wzrostu przeciętnego wynagrodzenia. Retrieved from: https://stat.gov.pl/ sygnalne/komunikaty-i-obwieszczenia/lista-komunikatow-i-obwieszczen/komunikat-w-sprawie-realnego-wzrostu-przecietnego-wynagrodzenia-w-2018-roku-wstosunku-do-2017-roku,274,6.html (accessed: 31.10.2020). 
Komunikat Prezesa Głównego Urzędu Statystycznego z dnia 11 lutego 2019 r. w sprawie realnego wzrostu przeciętnego wynagrodzenia. Retrieved from: https://stat.gov.pl/ sygnalne/komunikaty-i-obwieszczenia/lista-komunikatow-i-obwieszczen/komunikat-w-sprawie-realnego-wzrostu-przecietnego-wynagrodzenia-w-2018-roku-wstosunku-do-2017-roku,274,6.html (accessed: 31.10.2020).

Lorkowski, J. (2019). Direct and indirect costs of increasing the amount of documentation in force in the treatment of patients in trauma and orthopaedic departments. Warszawa: MBA SGH/WUM diploma thesis (Thesis supervisor prof. M. RaulinajtysGrzybek).

Lorkowski, J., \& Jugowicz, A. (2020). The historical determinations of creating health records - A new approach in terms of the ongoing Covid-19 Pandemic. Preprints.

Lorkowski, J., Maciejowska-Wilcock, I., \& Pokorski, M. (2020). Overload of medical documentation: A disincentive for healthcare professionals. Advances in Experimental Medicine and Biology, 10 (in press).

Lorkowski, J., \& Malinowska, M. (2020). The future of medical documentation - Review of selected literature. Preprints.

Lorkowski, J., \& Wilk, R. (2017). Nonmedical aspect of working time of resident doctors in Poland related to the creation of medical records. Ostry Dyż, 10(4), 100-107.

Maslach, C., \& Schaufeli, W.B. (1993). Historical and conceptual development of burnout. In: Schaufeli, WB, Maslach, C, Marek, T Eds.), Professional burnout: Recent developments in theory and research. Washington DC: Taylor and Francis.

Mearian, L. (2018). Amazon launches patient data-mining service to assist docs. Computerworld. Retrieved from: https://www.computerworld.com/article/3324044/amazonlaunchespatient-data-mining-service-to-assist-docs.html (accessed: 1.8.2019).

Parkinson, C.N. (1971). Prawo Parkinsona albo w pogoni za postępem, Edition III. Warszawa: Wydawnictwo "Książka i Wiedza".

Przyrost dokumentów - czy jest jakieś wyjście? Na Temat, 24.04.2014. Retrieved from: http://natemat.pl/99661, przyrost-dokumentow-czy-jest-jakies-wyjscie (accessed: 1.6.2019).

Reiser, S.J. (2009). Technological medicine: The changing world of doctors and patients. New York: Cambridge University Press.

Reiser, S.J. (1991). The clinical record in medicine. Part 2: reforming content and purpose. Annals of Internal Medicine, 114(11), 980-985.

Rostkowski, T. (2018). Dylematy wyższej kadry kierowniczej w zarzq̨dzaniu kapitałem ludzkim. Warszawa: Wydawnictwo Rozwoju Kapitału Ludzkiego.

Siegler, E.L. (2010). The evolving medical record. Annals of Internal Medicine, 153(10), 671-677.

Tait, I. (1981). History of our records. The British Medical Journal, 282, 702-703.

The Swedish knee arthroplasty register (2014). Bone \& Joint Research, 3(7), 217-222.

Tischner J. (2000). Myśli wyszukane. Kraków: SIW Znak.

VRIO Framework. Retrieved from: https://www.strategicmanagementinsight.com/ tools/vrio.html (accessed: 1.6.2020). 


\section{Jacek Lorkowski}

MD, Associate Professor, orthopaedic surgeon. Author of several hundred publications (articles, textbooks, chapters in textbooks), mainly in medical field. Especially interested in artificial intelligence, in silico modelling, orthopaedics, biomechanics and economic processes, mainly in medicine.

e-mail: jacek.lorkowski@gmail.com

ORCID 0000-0001-5985-9790

\section{Oliwia Grzegorowska}

MD, graduate of Pomeranian Medical University, cardiology resident. Member of the European Society of Cardiology. Author of numerous articles in the medical field. Interested in artificial intelligence affecting current life, improving medical knowledge and procedures, especially in cardiology.

e-mail: oliwia.grzegorowska@gmail.com

ORCID 0000-0002-7543-7990 